\title{
Molecular Epidemiology of Azole-Resistant Aspergillus fumigatus in Sawmills of Eastern France by Microsatellite Genotyping
}

\author{
Audrey Jeanvoine ${ }^{1}$, Chloé Godeau ${ }^{2}$, Audrey Laboissière ${ }^{2}$, Gabriel Reboux ${ }^{1,2}$, \\ Laurence Millon 1,2 (D) and Steffi Rocchi 1,2,*(D) \\ 1 Parasitology-Mycology Department, University Hospital of Besançon, 25000 Besançon, France; \\ ajeanvoine@chu-besancon.fr (A.J.); gabriel.reboux@univ-fcomte.fr (G.R.); lmillon@chu-besancon.fr (L.M.) \\ 2 Chrono-Environnement UMR 6249 CNRS, Bourgogne Franche-Comté University, 25000 Besançon, France; \\ chloe.godeau@univ-fcomte.fr (C.G.); audrey.laboissiere@univ-fcomte.fr (A.L.) \\ * Correspondence: steffi.rocchi@univ-fcomte.fr
}

Received: 25 June 2020; Accepted: 22 July 2020; Published: 26 July 2020

check for updates

\begin{abstract}
Background: Wood chipping has been described as a potential hotspot for the selection of azole-resistant Aspergillus fumigatus (ARAf). We previously reported ARAf isolates in sawmills (Eastern France), most of which contained the TR ${ }_{34} / \mathrm{L} 98 \mathrm{H}$ mutation. Methods: To study genotypic relatedness, microsatellite genotyping (short tandem repeat for $A$. fumigatus (STR $A f$ )) was performed on 41 azole-susceptible $A$. fumigatus (ASAf) and 23 ARAf isolated from 18 sawmills and two clinical A. fumigatus (sensitive and resistant) isolated from a sinus sample of a woodworker. Results: Fifty-four unique multilocus genotypes (MLGs) were described among the 66 isolates: 13/24 ARAf and 41/42 ASAf. Allelic diversity was higher for ASAf than for ARAf. Among the 24 ARAf, five isolates had their own MLGs. Thirteen ARAf (54\%) belonged to the same group, composed of four close MLGs, defined using Bruvo's distance. Thirty-two of the 42 ASAf $(76 \%)$ had their own MLGs and could not be grouped with the Bruvo's distance cutoff used (0.2). Conclusion: Thus, at a regional scale and in the particular environment of the wood industry, common but also different distinct genotypes, even in the same sawmill, were identified. This suggests that the hypothesis of ARAf clonal expansion from a common strain is probably insufficient to explain genotype emergence and distribution.
\end{abstract}

Keywords: Aspergillus fumigatus; azole-resistant; sawmill; microsatellite; multilocus genotype

\section{Introduction}

Aspergillus fumigatus is a saprophytic fungus that is widespread in the environment with an ecological niche of decaying vegetation and soil [1]. It is also a ubiquitously opportunistic pathogen responsible for aspergillosis, notably invasive aspergillosis (IA) - the most severe form of the disease [2]. Indeed, the IA mortality rate is high and can reach $65 \%$ [3].

Although azole antifungals improve the management of Aspergillus-disease, this clinical advance might be threatened by the emergence of azole-resistant $A$. fumigatus (ARAf) worldwide [4,5]. Over the past 20 years, there have been increasing reports of ARAf recovered on the five continents both in clinical and environmental samples [4]. The environmental route of resistance, based on the wide scale use of azole fungicides in the environment, plays a significant role [6]. Two main mechanisms of resistance that are probably of environmental origin, $\mathrm{TR}_{34} / \mathrm{L} 98 \mathrm{H}$ and $\mathrm{TR}_{46} / \mathrm{Y} 121 \mathrm{~F} / \mathrm{T} 289 \mathrm{~A}$ mutations, have commonly been described in strains from azole-naïve patients and from the environment $[4,5]$.

Over the past few years, several environmental areas have been reported as potential hotspots for the selection of ARAf. In the Netherlands, composts containing azole residues constitute a potential hotspot for the emergence of new mutations conferring resistance [7]. Recently, wastes 
originating from flower bulbs, green materials, and wood chippings have been reported to be three new hotspots containing azole fungicides with the highest proportion of ARAf, as compared to wheat cereals, animal manure, grain, maize silage, fruit storage or regional and exotic fruit waste [8]. ARAf have been identified in wood environments for some years now. In fact, ARAf carrying TR $34 / \mathrm{L} 98 \mathrm{H}$ and $\mathrm{TR}_{46} / \mathrm{Y} 121 \mathrm{~F} / \mathrm{T} 289 \mathrm{~A}$ have been described in wood debris of tree trunk hollows in Tanzania and Romania [9]. We also previously described the presence of ARAf in the wood environment, namely sawmills of Eastern France, most of which carried the $\mathrm{TR}_{34} / \mathrm{L} 98 \mathrm{H}$ mutation [10]. In this previous study, the presence of $\mathrm{AR} A f$ carrying the $\mathrm{TR}_{34} / \mathrm{L} 98 \mathrm{H}$ mutation seemed to greatly depend on the azole fungicide formulation and the quantity in substrates [10].

Consequently, the azole fungicide selection pressure could occur in different environments and in different countries and seems to play an important role in the selection of ARAf. Although typing of A. fumigatus isolates could provide insights into the dynamics of azole resistance development, the origin and global diffusion of azole-resistant $A$. fumigatus with $\mathrm{TR}_{34} / \mathrm{L} 98 \mathrm{H}$ and $\mathrm{TR}_{46} / \mathrm{Y} 121 \mathrm{~F} / \mathrm{T} 289 \mathrm{~A}$ are still unclear $[11,12]$. Currently, short tandem repeat for $A$. fumigatus assay (STRAf), based on a nine microsatellite analysis, is accepted as the reference and robust typing method for this species $[13,14]$.

The aim of this study was to genotype ARA $f$ and azole-susceptible $A$. fumigatus (ASAf), previously isolated from sawmills of Eastern France, by using STRAf typing in order to study their genetic relatedness and to describe the potential clustering of isolates according to their susceptibility profile [10]. In addition, the clinical isolates (sensitive and $\mathrm{TR}_{34} / \mathrm{L} 98 \mathrm{H}$ ) previously described in an immunocompetent woodworker with invasive sinusal aspergillosis were compared to the sawmill isolates [15].

\section{Materials and Methods}

\subsection{Collection of A. fumigatus Strains}

A total of 64 environmental A. fumigatus strains, isolated from 18 French sawmills (Eastern France) between September 2014 and April 2016, were analyzed (Table 1). Among them, 23 ARAf isolates had previously been isolated by using two selective homemade malt extract agar (ThermoFisher, Waltham, MA, USA) media containing azole antifungals: itraconazole called "Maltitra" and voriconazole called "Maltvori" [10]. The 41 selected ASAf isolates matched according to the location of ARA $f$ isolates for each sawmill. Two clinical isolates (one ARAf and one ASAf), isolated from sinus samples in an immunocompetent woodworker who developed an invasive sinusal aspergillosis following facial injuries from a work-related accident, were also included (Table 1) [15].

All A. fumigatus isolates were identified to the species level by PCR amplification and sequencing a part of the highly conserved $\beta$-tubulin gene [10].

For all ARAf, minimal inhibitory concentrations (MIC) of four medical azoles (itraconazole, voriconazole, posaconazole and isavuconazole) and two azoles used in agriculture and sawmills (propiconazole and tebuconazole) were obtained by using the EUCAST (European Committee on Antimicrobial Susceptibility) microdilution method [16].

Amplification and sequencing of the cyp51A gene were performed as previously described [10]. Among the 23 environmental ARAf, 20 carried the $\mathrm{TR}_{34} / \mathrm{L} 98 \mathrm{H}$ mutation, two the TR $34 / \mathrm{L} 98 \mathrm{H} / \mathrm{S} 297 \mathrm{~T} / \mathrm{F} 495 \mathrm{I}$ mutation and one the P216L mutation [10]. The clinical ARAf, one of the two isolates recovered in the woodworker, also carried the $\mathrm{TR}_{34} / \mathrm{L} 98 \mathrm{H}$ mutation [15].

MIC of voriconazole and itraconazole for environmental and clinical ASAf isolates were measured by the EUCAST method [16]. 
Table 1. Characteristics of analyzed azole-resistant (ARAf) and azole-susceptible (ASAf) A. fumigatus.

\begin{tabular}{|c|c|c|c|}
\hline Isolate Identification & Date of Isolation & Origin & $\begin{array}{l}\text { Susceptible or Resistant and } \\
\text { Cyp51A Mutation }\end{array}$ \\
\hline $\mathrm{A} 25$ & February 2015 & Substrate, sawmill A & Resistant, $\mathrm{TR}_{34} / \mathrm{L} 98 \mathrm{H}$ \\
\hline $\mathrm{D} 2$ & January 2016 & Substrate, sawmill D & Resistant, $\mathrm{TR}_{34} / \mathrm{L} 98 \mathrm{H}$ \\
\hline D3 & January 2016 & Substrate, sawmill D & Resistant, $\mathrm{TR}_{34} / \mathrm{L} 98 \mathrm{H}$ \\
\hline D4 & January 2016 & Substrate, sawmill D & Resistant, $\mathrm{TR}_{34} / \mathrm{L} 98 \mathrm{H}$ \\
\hline D5 & January 2016 & Substrate, sawmill D & Resistant, $\mathrm{TR}_{34} / \mathrm{L} 98 \mathrm{H} / \mathrm{S} 297 \mathrm{~T} / \mathrm{F} 495 \mathrm{I}$ \\
\hline D6 & January 2016 & Substrate, sawmill D & Resistant, $\mathrm{TR}_{34} / \mathrm{L} 98 \mathrm{H}$ \\
\hline D7 & January 2016 & Substrate, sawmill D & Resistant, $\mathrm{TR}_{34} / \mathrm{L} 98 \mathrm{H}$ \\
\hline D8 & January 2016 & Substrate, sawmill D & Resistant, $\mathrm{TR}_{34} / \mathrm{L} 98 \mathrm{H}$ \\
\hline F13 & February 2016 & Substrate, sawmill F & Resistant, $\mathrm{TR}_{34} / \mathrm{L} 98 \mathrm{H}$ \\
\hline F14 & February 2016 & Substrate, sawmill F & Resistant, $\mathrm{TR}_{34} / \mathrm{L} 98 \mathrm{H} / \mathrm{S} 297 \mathrm{~T} / \mathrm{F} 495 \mathrm{I}$ \\
\hline G15 & February 2016 & Substrate, sawmill G & Resistant, $\mathrm{TR}_{34} / \mathrm{L} 98 \mathrm{H}$ \\
\hline H16 & February 2016 & Substrate, sawmill H & Resistant, $\mathrm{TR}_{34} / \mathrm{L} 98 \mathrm{H}$ \\
\hline K17 & March 2016 & Substrate, sawmill K & Resistant, $\mathrm{TR}_{34} / \mathrm{L} 98 \mathrm{H}$ \\
\hline M18 & March 2016 & Substrate, sawmill M & Resistant, $\mathrm{TR}_{34} / \mathrm{L} 98 \mathrm{H}$ \\
\hline O19 & March 2016 & Substrate, sawmill O & Resistant, $\mathrm{TR}_{34} / \mathrm{L} 98 \mathrm{H}$ \\
\hline $\mathrm{O} 20$ & March 2016 & Substrate, sawmill O & Resistant, $\mathrm{TR}_{34} / \mathrm{L} 98 \mathrm{H}$ \\
\hline P11 & September 2014 & Substrate, sawmill P & Resistant, $\mathrm{TR}_{34} / \mathrm{L} 98 \mathrm{H}$ \\
\hline P12 & September 2014 & Substrate, sawmill P & Resistant, $\mathrm{TR}_{34} / \mathrm{L} 98 \mathrm{H}$ \\
\hline Q10 & January 2016 & Substrate, sawmill R & Resistant, $\mathrm{TR}_{34} / \mathrm{L} 98 \mathrm{H}$ \\
\hline $\mathrm{R} 21$ & April 2016 & Substrate, sawmill S & Resistant, $\mathrm{TR}_{34} / \mathrm{L} 98 \mathrm{H}$ \\
\hline $\mathrm{R} 22$ & April 2016 & Substrate, sawmill S & Resistant, $\mathrm{TR}_{34} / \mathrm{L} 98 \mathrm{H}$ \\
\hline $\mathrm{S} 23$ & April 2016 & Substrate, sawmill T & Resistant, $\mathrm{TR}_{34} / \mathrm{L} 98 \mathrm{H}$ \\
\hline S24 & April 2016 & Substrate, sawmill T & Resistant, $\mathrm{TR}_{34} / \mathrm{L} 98 \mathrm{H}$ \\
\hline Wood-worker & October 2013 & Clinical & Resistant, $\mathrm{TR}_{34} / \mathrm{L} 98 \mathrm{H}$ \\
\hline A175 & February 2015 & Substrate, sawmill A & Susceptible \\
\hline A176 & February 2015 & Substrate, sawmill A & Susceptible \\
\hline A177 & February 2015 & Substrate, sawmill A & Susceptible \\
\hline A178 & February 2015 & Substrate, sawmill A & Susceptible \\
\hline $\mathrm{C} 1 \mathrm{P}$ & January 2016 & Substrate, sawmill C & Susceptible \\
\hline D156 & January 2016 & Substrate, sawmill D & Susceptible \\
\hline D157 & January 2016 & Substrate, sawmill D & Susceptible \\
\hline D158 & January 2016 & Substrate, sawmill D & Susceptible \\
\hline D159 & January 2016 & Substrate, sawmill D & Susceptible \\
\hline D161 & January 2016 & Substrate, sawmill D & Susceptible \\
\hline D162 & January 2016 & Substrate, sawmill D & Susceptible \\
\hline D9P & January 2016 & Substrate, sawmill D & Susceptible \\
\hline D10P & January 2016 & Substrate, sawmill D & Susceptible \\
\hline E21P & January 2016 & Substrate, sawmill E & Susceptible \\
\hline F19P & February 2016 & Substrate, sawmill F & Susceptible \\
\hline F20P & February 2016 & Substrate, sawmill F & Susceptible \\
\hline F163 & February 2016 & Substrate, sawmill F & Susceptible \\
\hline G24P & February 2016 & Substrate, sawmill G & Susceptible \\
\hline $\mathrm{H} 22 \mathrm{P}$ & February 2016 & Substrate, sawmill H & Susceptible \\
\hline $\mathrm{H} 23 \mathrm{P}$ & February 2016 & Substrate, sawmill H & Susceptible \\
\hline H164 & February 2016 & Substrate, sawmill H & Susceptible \\
\hline $\mathrm{I} 15 \mathrm{P}$ & February 2016 & Substrate, sawmill I & Susceptible \\
\hline $\mathrm{J} 16 \mathrm{P}$ & March 2016 & Substrate, sawmill J & Susceptible \\
\hline $\mathrm{K} 2 \mathrm{P}$ & March 2016 & Substrate, sawmill K & Susceptible \\
\hline K165 & March 2016 & Substrate, sawmill K & Susceptible \\
\hline $\mathrm{L} 4 \mathrm{P}$ & March 2016 & Substrate, sawmill L & Susceptible \\
\hline M5P & March 2016 & Substrate, sawmill M & Susceptible \\
\hline N6P & March 2016 & Substrate, sawmill N & Susceptible \\
\hline O7P & March 2016 & Substrate, sawmill O & Susceptible \\
\hline $\mathrm{O} 8 \mathrm{P}$ & March 2016 & Substrate, sawmill O & Susceptible \\
\hline O166 & March 2016 & Substrate, sawmill O & Susceptible \\
\hline $\mathrm{P} 173$ & September 2014 & Substrate, sawmill P & Susceptible \\
\hline P174 & September 2014 & Substrate, sawmill P & Susceptible \\
\hline Q17P & January 2016 & Substrate, sawmill R & Susceptible \\
\hline$\hat{\mathrm{R}} 11 \mathrm{P}$ & April 2016 & Substrate, sawmill S & Susceptible \\
\hline $\mathrm{R} 12 \mathrm{P}$ & April 2016 & Substrate, sawmill S & Susceptible \\
\hline R168 & April 2016 & Substrate, sawmill S & Susceptible \\
\hline $\mathrm{S} 13 \mathrm{P}$ & April 2016 & Substrate, sawmill T & Susceptible \\
\hline S14P & April 2016 & Substrate, sawmill T & Susceptible \\
\hline S169 & April 2016 & Substrate, sawmill T & Susceptible \\
\hline S179 & April 2016 & Substrate, sawmill T & Susceptible \\
\hline Wood-worker & July 2013 & Clinical & Susceptible \\
\hline
\end{tabular}




\subsection{Short Tandem Repeat for A. fumigatus (STRAf) Typing and Analysis}

STR $A f$ typing is based on the amplification of nine highly polymorphic microsatellite markers (STRAfs 2A, 2B, 2C, 3A, 3B, 3C, 4A, 4B, 4C). These nine STRAf loci were amplified with three triplexed PCRs as previously described [13].

PCR products were diluted 10-fold with water for molecular biology and then analyzed on the Applied Biosystems 3130 Genetic Analyzer (ThermoFisher, Waltham, MA, USA) with GeneScan ${ }^{\mathrm{TM}} 400 \mathrm{HD}^{\mathrm{ROO}}{ }^{\mathrm{TM}}$ size standard according to the manufacturer's instructions (Thermofisher ${ }^{\circledR}$, Waltham, MA, USA).

Amplicon sizes were determined with GeneMapper software (version 5, ThermoFisher, Waltham, MA, USA) and then transformed in repeat number.

STRA $f$ analysis was then performed using RStudio software (version 3.2.2, Boston, MA, USA). Microsatellite genotype distances were calculated using Bruvo's distance (cutoff value $=0.2$ ) and a minimum spanning network was calculated via the bruvo.msn function on the poppr library [17]. Finally, allelic diversity was calculated for the nine STR $A f$ loci for ARA $f$ and ASA $f$ isolates by using the Simpson index of diversity $(D)$.

\section{Results}

A total of 54 STR $A f$ unique multilocus genotypes (MLGs) were described among the 66 typed A. fumigatus: 13 for the 24 ARAf and 41 for the 42 ASAf. None of the ARAf isolates had MLGs close to those that of the ASAf isolates, and the sensitive clinical isolate identified in the woodworker before the resistant one revealed a completely different MLG.

The nine microsatellite markers including STRA $f$ genotypes, allele count, repeat range, median repeat number and allelic diversity are summarized in Table 2 . All loci were polymorphic with a number of alleles ranging from 3 (loci 3B and 4B) to 11 (locus 3A) and from 9 (locus 4B) to 19 (loci 3A and $3 \mathrm{C}$ ) for ARAf and ASAf isolates, respectively. Loci $3 \mathrm{~A}$ and $3 \mathrm{C}$ displayed the highest polymorphism and allelic diversity for both ARA $f$ and ASA $f$ isolates, whereas locus $4 \mathrm{~B}$ was the least discriminating with the lowest number of alleles (Table 2). For all microsatellite markers, allelic diversity was higher for ASAf isolates (average $D=0.811$ ) than for ARAf isolates (average $D=0.518$ ) (Table 2).

Table 2. Polymorphism information for the nine microsatellite markers obtained after short tandem repeat for $A$. fumigatus (STRAf) typing of sawmill azole-resistant (ARAf) and azole-susceptible (ASAf) A. fumigatus.

\begin{tabular}{|c|c|c|c|c|c|c|c|c|c|}
\hline \multicolumn{5}{|c|}{ Azole-Resistant $A$. fumigatus (AR $A f, n=24$ ) } & \multicolumn{5}{|c|}{ Azole-Susceptible $A$. fumigatus (AS $A f, n=42$ ) } \\
\hline $\begin{array}{l}\text { Microsatellite } \\
\text { Marker }\end{array}$ & $\begin{array}{c}\mathrm{N} \\
\text { Alleles }\end{array}$ & $\begin{array}{l}\text { Repeat } \\
\text { Range }\end{array}$ & $\begin{array}{l}\text { Median } \\
\text { Size }\end{array}$ & $\begin{array}{l}\text { Diversity } \\
\text { (D) }\end{array}$ & $\begin{array}{l}\text { Microsatellite } \\
\text { Marker }\end{array}$ & $\begin{array}{c}\text { N } \\
\text { Alleles }\end{array}$ & $\begin{array}{l}\text { Repeat } \\
\text { Range }\end{array}$ & $\begin{array}{l}\text { Median } \\
\text { Size }\end{array}$ & $\begin{array}{c}\text { Diversity } \\
\text { (D) }\end{array}$ \\
\hline $2 \mathrm{~A}$ & 5 & $13-26$ & 14 & 0.507 & $2 \mathrm{~A}$ & 11 & $10-27$ & 18 & 0.768 \\
\hline $2 \mathrm{~B}$ & 4 & $10-24$ & 21 & 0.462 & $2 \mathrm{~B}$ & 9 & $12-25$ & 19 & 0.766 \\
\hline $2 \mathrm{C}$ & 4 & $8-16$ & 8 & 0.552 & $2 \mathrm{C}$ & 11 & $8-20$ & 12 & 0.868 \\
\hline $3 \mathrm{~A}$ & 11 & $10-119$ & 32 & 0.872 & $3 \mathrm{~A}$ & 19 & $10-49$ & 26 & 0.909 \\
\hline $3 B$ & 3 & 8-11 & 8 & 0.403 & $3 \mathrm{~B}$ & 10 & $8-22$ & 9 & 0.771 \\
\hline $3 C$ & 7 & $6-32$ & 6 & 0.649 & $3 C$ & 19 & $6-45$ & 18 & 0.924 \\
\hline $4 \mathrm{~A}$ & 5 & $5-18$ & 8 & 0.361 & $4 \mathrm{~A}$ & 13 & $7-26$ & 9 & 0.774 \\
\hline $4 \mathrm{~B}$ & 3 & $7-10$ & 10 & 0.392 & $4 \mathrm{~B}$ & 8 & $5-26$ & 9 & 0.746 \\
\hline $4 \mathrm{C}$ & 5 & $5-30$ & 20 & 0.465 & $4 \mathrm{C}$ & 9 & $5-36$ & 7 & 0.770 \\
\hline Total alleles & 47 & NR & NR & NR & Total alleles & 109 & NR & NR & NR \\
\hline Average D & NR & NR & NR & 0.518 & Average D & NR & NR & NR & 0.811 \\
\hline
\end{tabular}

N Alleles = Allele counts; $D=$ Simpson index of diversity; $\mathrm{NR}=$ non relevant.

Among the 42 ASAf, 41 MLGs were identified, with two isolates from two different sawmills (A and D, $60 \mathrm{~km}$ away) sharing the same genotype (A177 and D159, Figure 1). Thirty-two MLGs $(76 \%)$ were very distinct and could not be grouped with the Bruvo distance cutoff used. However, four groups of two ASAf were found: D161 and R12P, E21P and O166, S179 and C1P, F20P and F19P 
(genotypes connected by lines in Figure 1). These ASAf were isolated from different sawmills, except for isolates F20P and F19P which were recovered in the same sawmill (F) at different locations.

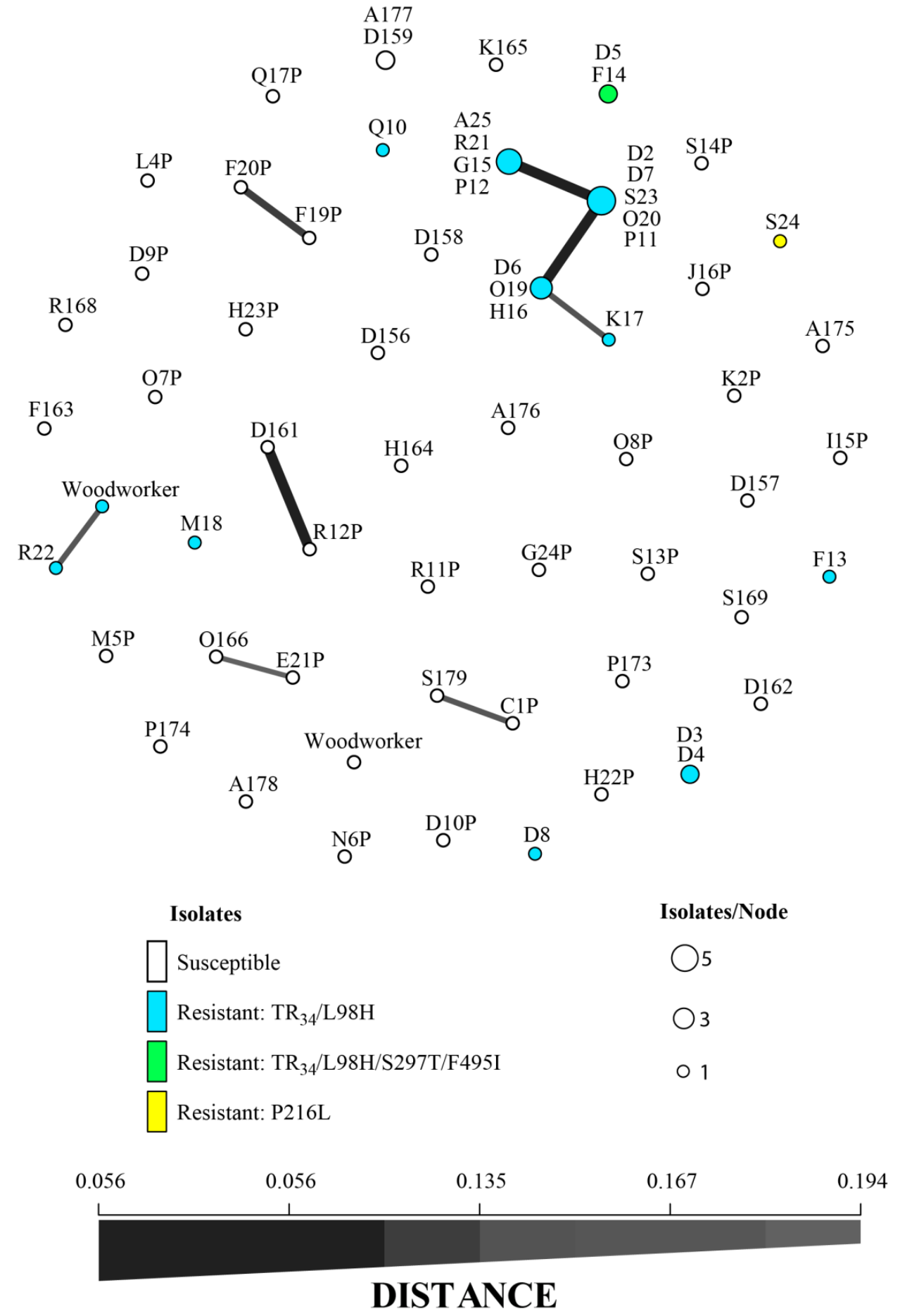

Distance Bruvo / Network (cutoff $<0.2$ )

Figure 1. Minimum spanning network of nine microsatellite loci STRA $f$ using Bruvo's distance. Letters correspond to sawmill and the following numbers \pm letters are genotype numbers. Each circle represents one multilocus genotype, the size of which is proportional to frequency. Different colors represent the different isolates (susceptible or resistant, and their mutations on the Cyp51A gene and its promoter). Link thickness is proportional to genotype similarity. 
Among the $24 \mathrm{ARAf}, 13$ MLGs were characterized. Four isolates with the $\mathrm{TR}_{34} / \mathrm{L} 98 \mathrm{H}$ mutation (genotype numbers Q10, M18, D8 and F13, Figure 1) and one with the P216L mutation (genotype S24) had their own MLGs and could not be grouped with Bruvos's distance. The others were recovered for several isolates grouped in the same circles within the minimum spanning network (Figure 1).

For $\mathrm{TR}_{34} / \mathrm{L} 98 \mathrm{H}$ isolates, two MLGs that were genotypically distinct from others were identified: genotypes D3 and D4 with the $\mathrm{TR}_{34} / \mathrm{L} 98 \mathrm{H}$ mutation, found in the same soil sample, and D5 and F14 with the TR $34 / \mathrm{L} 98 \mathrm{H} / \mathrm{S} 297 \mathrm{~T} / \mathrm{F} 495 \mathrm{I}$, taken from two geographically distant sawmills $(170 \mathrm{~km})$.

Moreover, two groups of MLGs were found with Bruvo's distance (Figure 1). The first group was composed of four MLGs, including 13/24 ARAf (54\%, genotype numbers A25, R21, G15, P12 / D2, D7, S23, O20, P11 / D6, O19, H16 and K17). Among these four closely related STRA $f$ genotypes, three differed by only one repetition of the microsatellite marker 3A; the fourth (K17 ARAf) differed from the three others by the number of repetitions of microsatellite markers $3 \mathrm{~A}$ and $3 \mathrm{C}$. These four genotypes included $\mathrm{TR}_{34} / \mathrm{L} 98 \mathrm{H}$ ARAf isolated from different sawmills that could be located as far as $200 \mathrm{~km}$ from each other; two of these genotypically similar ARAf (P11 and P12) were isolated in one sawmill that imported wood from Russia. The second group consisted of one clinical $\mathrm{TR}_{34} / \mathrm{L} 98 \mathrm{H}$ isolate responsible for invasive sinusal aspergillosis in an immunocompetent woodworker and had a genotype close to a sawmill ARAf also carrying the TR $34 / \mathrm{L} 98 \mathrm{H}$ mutation (genotype $\mathrm{R} 22$ in Figure 1). It differed by the number of repetitions on microsatellite markers $3 \mathrm{~A}$ and $4 \mathrm{~A}$. However, the woodworker did not work in sawmill R.

Identical MLGs were thus found in different sawmills, but different MLGs were also found in one sawmill: five different MLGs were identified among the seven ARAf found in sawmill D. This sawmill shared one MLG (genotype D5, mutation TR $34 / \mathrm{L} 98 \mathrm{H} / \mathrm{S} 297 \mathrm{~T} / \mathrm{F} 495 \mathrm{I}$ ) with another sawmill. Sawmill D shared MLGs with other sawmills and genotypes that closely resembled each other (genotypes D2, D7 and D6). It also had one MLG (genotypes D3 and D4) that was different from all other MLGs.

\section{Discussion}

In this study, we reported the presence of both common and different genotypes in ARA $f$ and ASA $f$ from sawmills of Eastern France by using STR $A f$ typing. Our findings are similar to those of several other studies, as we reported that ASAf had a greater genotypic diversity than ARA $f[14,18,19]$. This could suggest a predominantly clonal expansion of ARAf in the environment. In fact, contrary to ASAf, more than half of ARAf (54\%) belonged to the same group with the Bruvo's distance cutoff used and seemed to be genotypically close. These ARAf came from different sawmills that were geographically far from one another (up to $200 \mathrm{~km}$ ) and for which a selection pressure by azole fungicide was reported. Direct or indirect contact with azole fungicide was shown, and azole fungicides were detected in substrate samples in these sawmills [10].

This study has some limitations. First, we describe here the genotypic structure of isolates coming from only one region in France and one type of environment. A broader study including genotyping of isolates from other regions, environments and countries would make it possible to know if the genotypes of ARA $f$ and ASAf from Eastern France are shared by isolates in other regions of the world; this could help to improve our understanding of the emergence, diffusion and distribution of ARAf.

In addition, we used STR $A f$ typing which is widely accepted as the reference typing method for A. fumigatus [14]. However, two of the nine microsatellite markers, 3A and 3C, show a lower level of stability which has to be taken into account when interpreting STR $A f$ data during molecular epidemiological analysis [20]. This is illustrated by the greater polymorphisms for these two markers described in our study. Moreover, three genotypes differed by only one repetition on marker 3A and grouped isolates coming from the same sawmill or the same samples (P11 and P12). The difference between these three genotypes might be valid but we cannot exclude a bias in the genotyping method used. Despite the high discriminatory power of STRAf typing, it remains lower than that of whole genome sequencing (WGS). So, it would be interesting to determine whether or not ARAf with the 
same genotype, revealed using STRA $f$ typing, would reveal exactly the same genotype when using WGS. Likewise, exploring genotypic diversity with WGS could be useful.

It is important to emphasize that 13 STRAf genotypes were found among the 24 ARAf. Moreover, some ARAf had their own genotypes and were genotypically distinct from others despite sharing the same mechanism of resistance (mutation $\mathrm{TR}_{34} / \mathrm{L} 98 \mathrm{H}$ ). It is interesting to note that this diversity was reported in one sawmill (D), without any particular characteristics when compared to other sawmills using a dip processing tank, and where five MLGs were reported among the seven ARAf genotyped. These findings contrast with those of some studies describing only one clone of $\mathrm{TR}_{34} / \mathrm{L} 98 \mathrm{H}$ ARAf strains $[18,21]$. The local diversity of the genotype reported here was also highlighted for ARAf isolates in market gardens of the same region in Eastern France. In this study, 22 STRAf genotypes among 44 analyzed ARAf and six groups of genotypically close ARAf were recorded. ARA $f$ isolates could be more diverse in other countries such as Colombia where 19 MLGs were identified in 21 ARAf isolates in the environment $[17,22]$. Additionally, it has also been shown by STR $A f$ typing that resistant isolates, coming from several countries, belonged to several groups. Similarly, some authors have reported a dispersed structure in ARAf with tandem repeat (TR) mutations [11,14]. Thus, it seems unlikely that the emergence of azole-resistant strains could be the work of a single clone.

The population structure of $A$. fumigatus is very complex and is likely to be due to several past and current events: historical differentiation, contemporary gene flow, sexual reproduction, recombination, and the localized azole fungicide selection that could drive expansion of ARA $f$ genotypes [11,12]. It was recently reported that certain practices like composting (i.e., stockpiling plant waste) might be the key to resistance selection in A. fumigatus [8]. Some environments supporting the growth, sexual reproduction, genetic variation and containing residues of azole fungicides could cause these complex mutations to emerge, amplify and spread. So, ARAf may very well emerge in specific environments and spread to other countries due to natural factors such as wind, or anthropogenic factors such as human travel and commercial trade [11,23]. This gene flow could explain the fact that genotypically close ARAf, or those having the same genotype, were found in different countries $[18,19,21]$.

A comparison of genotypes from sawmill ARAf with genotypes from other $A$. fumigatus isolates in a London database (https://afumid.shinyapps.io/afumID/, 4049 A. fumigatus isolates collected worldwide) showed that some sawmill ARAf (A25, R21, G15, P12 with the same MLG) presented the same genotype as a clinical Australian isolate (data not shown). Among them, isolate P12 is one of the two isolates found in one sawmill that did not treat wood, but rather imported foreign wood from Russia that had already been treated with fungicides (sawmill P). Curiously, these two ARAf shared the same MLG as other sawmills ARAf. According to these results, the gene flow could not be excluded here and it may be possible that these ARAf emerged in a favorable environment outside of France and then, when imported, spread to the Eastern France sawmills. Conversely, an MLG identified twice in a single sawmill (D) is not linked to any profile in the London database.

The distribution of sawmill ARA $f$ and ASAf genotypes, with a lower diversity of ARAf isolates, also seems to concur with two hypotheses reported by other authors to explain the emergence and distribution of ARAf: the specific genetic background and predisposition of some clones to develop azole-resistance, and the better ability of $\mathrm{AR} A f$ isolates to accept the azole-resistant genes via mating and recombination [11,14]. ARAf with $\mathrm{TR}_{34} / \mathrm{L} 98 \mathrm{H}$ and $\mathrm{TR}_{46} / \mathrm{Y} 121 \mathrm{~F} / \mathrm{T} 289 \mathrm{~A}$ mutations may have a genetic component that is restricting the resistance genotype to certain strains [24]. It has also been reported that the genetic backgrounds of $\mathrm{TR}_{34} / \mathrm{L} 98 \mathrm{H}$ and $\mathrm{TR}_{46} / \mathrm{Y} 121 \mathrm{~F} / \mathrm{T} 289 \mathrm{~A}$ ARA $f$ were less diversified than those of wild-type isolates [24]. This is compatible with selective gene sweeps accompanying the selection of beneficial mutations and the genetic adaptation of $A$. fumigatus which enable it to survive and reproduce in prevailing or new environments, such as those with azole fungicides [24,25]. Selective sweeps would reduce allelic diversity and one, or a limited number, of clones would predominate locally [23]. The lower allelic and STRAf genotype diversity reported for ARAf isolates from sawmills in our study make this hypothesis likely. So, according to their genetic background, some strains could adapt more easily than others to a given environment and could be more able to develop and persist 
in an environment where the azole fungicide selection pressure is substantial. Moreover, the lower diversity of the ARAf, despite their different origin and the fact that they have been isolated in different sawmills, could suggest that ARAf belonging to the same group (with the Bruvo's distance cutoff used) are genotypically closed and probably evolved from each other.

In conclusion, in this study we reported both common and different genotypes on a regional scale. Despite having lower allelic diversity than ASAf isolates, some ARAf could not be grouped together with other sawmill ARAf isolates. The diversity of genotypes described here, at a local level, seems to support the multiple origins hypothesis, thus suggesting that the hypothesis of clonal expansion from a common strain is now probably obsolete and insufficient to explain ARA $f$ emergence and distribution. The evolution of ARAf from different origins could also be involved.

Author Contributions: Conceptualization, S.R., L.M. and A.J.; methodology, A.J., C.G. and A.L.; software, S.R. and A.J.; validation, S.R., L.M. and G.R.; formal analysis, A.J. and S.R.; investigation, S.R., L.M. and A.J.; resources, S.R. and L.M.; data curation, A.J. and S.R.; writing-original draft preparation, A.J.; writing—review and editing, S.R., L.M. and G.R.; visualization, A.J. and S.R.; supervision, S.R. and L.M.; project administration, L.M.; funding acquisition, S.R. and L.M. All authors have read and agreed to the published version of the manuscript.

Funding: This research received no external funding.

Acknowledgments: We thank Pamela Albert for her editorial assistance.

Conflicts of Interest: The authors declare no conflict of interest.

\section{References}

1. Snelders, E.; van der Lee, H.A.; Kuijpers, J.; Rijs, A.J.; Varga, J.; Samson, R.A.; Mellado, E.; Donders, A.R.T.; Melchers, W.J.G.; Verweij, P.E. Emergence of Azole Resistance in Aspergillus fumigatus and Spread of a Single Resistance Mechanism. PLoS Med. 2008, 5, e219. [CrossRef]

2. Verweij, P.E.; Snelders, E.; Kema, G.H.; Mellado, E.; Melchers, W.J. Azole resistance in Aspergillus fumigatus: A side-effect of environmental fungicide use? Lancet Infect. Dis. 2009, 9, 789-795. [CrossRef]

3. Verweij, P.E.; Kema, G.H.; Zwaan, B.; Melchers, W.J. Triazole fungicides and the selection of resistance to medical triazoles in the opportunistic mould Aspergillus fumigatus: The environmental route of azole resistance selection in Aspergillus fumigatus. Pest Manag. Sci. 2013, 69, 165-170. [CrossRef] [PubMed]

4. Jeanvoine, A.; Rocchi, S.; Bellanger, A.P.; Reboux, G.; Millon, L. Azole-resistant Aspergillus fumigatus: A global phenomenon originating in the environment? Med. Mal. Infect. 2019. [CrossRef]

5. Verweij, P.E.; Chowdhary, A.; Melchers, W.J.; Meis, J.F. Azole Resistance in Aspergillus fumigatus: Can We Retain the Clinical Use of Mold-Active Antifungal Azoles? Clin. Infect. Dis. 2016, 62, 362-368. [CrossRef] [PubMed]

6. Chowdhary, A.; Meis, J.F. Emergence of azole resistant Aspergillus fumigatus and One Health: Time to implement environmental stewardship. Environ. Microbiol. 2018, 20, 1299-1301. [CrossRef] [PubMed]

7. Zhang, J.; Snelders, E.; Zwaan, B.J.; Schoustra, S.E.; Meis, J.F.; van Dijk, K.; Hagen, F.; van der Beek, M.T.; Kampinga, G.A.; Zoll, J.; et al. A Novel Environmental Azole Resistance Mutation in Aspergillus fumigatus and a Possible Role of Sexual Reproduction in Its Emergence. mBio 2017, 8, e00791-17. [CrossRef]

8. Schoustra, S.E.; Debets, A.J.; Rijs, A.J.; Zhang, J.; Snelders, E.; Leendertse, P.C.; Melchers, W.J.; Rietveld, A.G.; Zwaan, B.J.; Verweij, P.E. Environmental Hotspots for Azole Resistance Selection of Aspergillus fumigatus, the Netherlands. Emerg. Infect. Dis. 2019, 25, 1347-1353. [CrossRef]

9. Sharma, C.; Hagen, F.; Moroti, R.; Meis, J.F.; Chowdhary, A. Triazole-resistant Aspergillus fumigatus harbouring G54 mutation: Is it de novo or environmentally acquired? J. Glob. Antimicrob. Resist. 2015, 3, 69-74. [CrossRef]

10. Jeanvoine, A.; Rocchi, S.; Reboux, G.; Crini, N.; Crini, G.; Millon, L. Azole-resistant Aspergillus fumigatus in sawmills of Eastern France. J. Appl. Microbiol. 2017, 123, 172-184. [CrossRef]

11. Ashu, E.E.; Hagen, F.; Chowdhary, A.; Meis, J.F.; Xu, J. Global Population Genetic Analysis of Aspergillus fumigatus. mSphere 2017, 2, e00019-17. [CrossRef] [PubMed]

12. Abdolrasouli, A.; Rhodes, J.; Beale, M.A.; Hagen, F.; Rogers, T.R.; Chowdhary, A.; Meis, J.F.; Armstrong-James, D.; Fisher, M.C. Genomic Context of Azole Resistance Mutations in Aspergillus fumigatus Determined Using Whole-Genome Sequencing. mBio 2015, 6, e00536-15. [CrossRef] [PubMed] 
13. de Valk, H.A.; Meis, J.F.; Curfs, I.M.; Muehlethaler, K.; Mouton, J.W.; Klaassen, C.H. Use of a Novel Panel of Nine Short Tandem Repeats for Exact and High-Resolution Fingerprinting ofAspergillus fumigatus Isolates. J. Clin. Microbiol. 2005, 43, 4112-4120. [CrossRef] [PubMed]

14. Garcia-Rubio, R.; Escribano, P.; Gomez, A.; Guinea, J.; Mellado, E. Comparison of Two Highly Discriminatory Typing Methods to Analyze Aspergillus fumigatus Azole Resistance. Front. Microbiol. 2018, 9, 1626. [CrossRef]

15. Jeanvoine, A.; Rocchi, S.; Reboux, G.; Grenouillet, F.; Benassarou, M.; Chirouze, C.; Millon, L. Sinus aspergillosis due to an azole-resistant Aspergillus fumigatus strain carrying the $\mathrm{TR}_{34} / \mathrm{L} 98 \mathrm{H}$ mutation in immunocompetent host. Infect. Dis. 2016, 48, 765-766. [CrossRef] [PubMed]

16. European Committee for Antimicrobial Susceptibility Testing (EUCAST). Available online: https://www. eucast.org/astoffungi/ (accessed on 24 June 2020).

17. Rocchi, S.; Ponçot, M.; Morin-Crini, N.; Laboissière, A.; Valot, B.; Godeau, C.; Léchenault-Bergerot, C.; Reboux, G.; Crini, G.; Millon, L. Determination of azole fungal residues in soils and detection of Aspergillus fumigatus-resistant strains in market gardens of Eastern France. Environ. Sci. Pollut. Res. 2018, 25, 32015-32023. [CrossRef]

18. Chowdhary, A.; Kathuria, S.; Xu, J.; Sharma, C.; Sundar, G.; Singh, P.K.; Gaur, S.N.; Hagen, F.; Klaassen, C.H.; Meis, J.F. Clonal Expansion and Emergence of Environmental Multiple-Triazole-Resistant Aspergillus fumigatus Strains Carrying the $\mathrm{TR}_{34} / \mathrm{L} 98 \mathrm{H}$ Mutations in the cyp51A Gene in India. PLoS ONE 2012, 7, e52871. [CrossRef]

19. Chang, H.; Ashu, E.; Sharma, C.; Kathuria, S.; Chowdhary, A.; Xu, J. Diversity and origins of Indian multi-triazole resistant strains of Aspergillus fumigatus. Mycoses 2016, 59, 450-466. [CrossRef]

20. de Groot, T.; Meis, J.F. Microsatellite Stability in STR Analysis Aspergillus fumigatus Depends on Number of Repeat Units. Front. Cell. Infect. Microbiol. 2019, 9, 82. [CrossRef]

21. Badali, H.; Vaezi, A.; Haghani, I.; Yazdanparast, S.A.; Hedayati, M.T.; Mousavi, B.; Ansari, S.; Hagen, F.; Meis, J.F.; Chowdhary, A. Environmental study of azole-resistant Aspergillus fumigatus with $\mathrm{TR}_{34} / \mathrm{L} 98 \mathrm{H}$ mutations in the cyp51A gene in Iran. Mycoses 2013, 56, 659-663. [CrossRef]

22. Alvarez-Moreno, C.; Lavergne, R.A.; Hagen, F.; Morio, F.; Meis, J.F.; Le Pape, P. Azole-resistant Aspergillus fumigatus harboring $\mathrm{TR}_{34} / \mathrm{L} 98 \mathrm{H}, \mathrm{TR}_{46} / \mathrm{Y} 121 \mathrm{~F} / \mathrm{T} 289 \mathrm{~A}$ and $\mathrm{TR}_{53}$ mutations related to flower fields in Colombia. Sci. Rep. 2017, 7, 45631. [CrossRef] [PubMed]

23. Korfanty, G.A.; Teng, L.; Pum, N.; Xu, J. Contemporary Gene Flow is a Major Force Shaping the Aspergillus fumigatus Population in Auckland, New Zealand. Mycopathologia 2019, 184, 479-492. [CrossRef]

24. Sewell, T.R.; Zhu, J.; Rhodes, J.; Hagen, F.; Meis, J.F.; Fisher, M.C.; Jombart, T. Nonrandom Distribution of Azole Resistance across the Global Population of Aspergillus fumigatus. mBio 2019, 10, e00392-19. [CrossRef] [PubMed]

25. Meis, J.F.; Chowdhary, A.; Rhodes, J.L.; Fisher, M.C.; Verweij, P.E. Clinical implications of globally emerging azole resistance in Aspergillus fumigatus. Philos. Trans. R. Soc. B Biol. Sci. 2016, 371, 20150460. [CrossRef] [PubMed]

(C) 2020 by the authors. Licensee MDPI, Basel, Switzerland. This article is an open access article distributed under the terms and conditions of the Creative Commons Attribution (CC BY) license (http://creativecommons.org/licenses/by/4.0/). 